\title{
Assistência de Enfermagem: História do Cuidado aos Pacientes Institucionalizados da Hanseníase
}

\author{
Dias, Mariana Barbosa; Nogueira, Lidya Tolstenko \\ Universidade Federal do Piauí — marianadias@hotmail.com
}

Introdução: a hanseníase, apesar dos significativos avanços para o diagnóstico, controle e tratamento, ainda é estigmatizada como enfermidade que implica isolamento do doente, marcado pelo sofrimento, abandono, problemas psicossociais e preconceito. no início dos anos 20 foi tratada por décadas com severas políticas de isolamento compulsório dos doentes em Hospitais Colônias. Devido ao preconceito, os próprios pacientes eram mantenedores dos serviços dentro das colônias, inclusive os de enfermagem. Objetivo: Conhecer a história dos ex-trabalhadores de enfermagem, que tiveram hanseníase e foram internados em Hospital Colônia no Piauí e analisar a assistência e o cuidado que exerciam com os pacientes institucionalizados da colônia. Metodologia: Esta é uma pesquisa qualitativa, com abordagem histórica, em Hospital Colônia no Piauí com 7 ex-pacientes de hanseníase. Os dados foram coletados por entrevistas com roteiro semiestruturado, pelo método da história oral, gravados e transcritos na íntegra, com uso da Análise de Conteúdo. Utilizou-se a História Oral como método-fonte-técnica e outras fontes documentais, como: atas, relatórios, prontuários e fotografias. o estudo foi aprovado pelo Comitê de Ética em Pesquisa da UFPI, 0326.0.045.000-10. Resultados: Foi descrito a definição de duas categorias: o aprendizado dos trabalhadores de enfermagem no Hospital Colônia e o cuidado dos trabalhadores de enfermagem e sua prática assistencial. Foi possível, ainda, desvelar como se caracterizou a Enfermagem laica de um hospital colônia, exercida pelos próprios pacientes e como se deu a construção dos saberes e fazeres na Enfermagem da época. Conclusão: Percebe-se que a prática do confinamento compulsório dos enfermos em instituições asilares contribuiu para solidificação histórica do preconceito em torno da doença e do doente. Observa-se a necessidade de gestores e profissionais locais da saúde, sobretudo os enfermeiros, repensarem as estratégias vigentes de reabilitação social do doente e ex-doente de hanseníase, visando à supressão do estigma focalizado na imagem e na história de vida desses indivíduos. Descritores: enfermagem, hanseníase, institucionalização.

Dias, Mariana Barbosa; Nogueira, Lidya Tolstenko. Assistência de Enfermagem: História do Cuidado aos Pacientes Institucionalizados da Hanseníase. In: Anais do Congresso Internacional de Humanidades \& Humanização em Saúde [= Blucher Medical Proceedings, num.2, vol.1]. São Paulo: Editora Blucher, 2014. ISSN 2357-7282

DOI 10.5151/medpro-cihhs-10722 